A Scenario Analysis of China's Land Use and Land Cover Change: Incorporating Biophysical Information into InputOutput Modeling

Klaus Hubacek and Laixiang Sun

RR-01-13

December 2001 


\section{A Scenario Analysis of China's Land Use and Land Cover Change: Incorporating Biophysical Information into Input- Output Modeling}

Klaus Hubacek

Economics Department, Rensselaer Polytechnic Institute, Troy, NY, USA

Laixiang Sun

International Institute for Applied Systems Analysis, Laxenburg, Austria

RR-01-13

December 2001

Reprinted from Structural Change and Economic Dynamics 12 (2001) 367-397. 
Research Reports, which record research conducted at IIASA, are independently reviewed before publication. Views or opinions expressed herein do not necessarily represent those of the Institute, its National Member Organizations, or other organizations supporting the work.

Reprinted with permission from Structural Change and Economic Dynamics 12 (2001) 367-397. Copyright (C) 2001 Elsevier Science

All rights reserved. No part of this publication may be reproduced or transmitted in any form or by any means, electronic or mechanical, including photocopy, recording, or any information storage or retrieval system, without permission in writing from the copyright holder. 


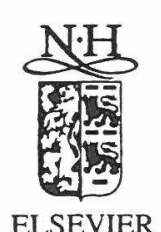

\begin{tabular}{cc} 
& \multicolumn{1}{c}{ STRUCTURAL } \\
& CHANGE AND \\
& ECONOMIC \\
Diructural Change and Economic Dynamics & DYNAMICS \\
$12(2001) 367-397$ & www.elsevier.com/locate/econbase
\end{tabular}

\title{
A scenario analysis of China's land use and land cover change: incorporating biophysical information into input-output modeling
}

\author{
Klaus Hubacek ${ }^{a, *}$, Laixiang Sun ${ }^{b}$ \\ a Economics Department, Rensselaer Polytechnic Institute, Troy, NY 12180, USA \\ b International Institute for Applied Systems Analysis (IIASA), Laxenburg, Austria
}

Received 1 January 2001; received in revised form 10 July 2001; accepted 3 August 2001

\begin{abstract}
This paper assesses how the widely perceived changes in the economy and society of China will affect future land use at the regional level. It also shows the consequences of these changes on future inter-regional and international trade flows of land-based products. In order to conduct an integrated and consistent assessment, we develop a mixed input-output model characterized by strong biophysical linkages and the incorporation of supply-constraints to the major land-consuming sectors. The spatial aspect of the assessment is provided by a number of fairly large and detailed geographical databases implemented in a geographical information system, including biophysical attributes of land and demographic distribution. (C) 2001 Elsevier Science B.V. All rights reserved.
\end{abstract}

JEL classification: $\mathrm{C} 67 ; \mathrm{N} 55 ; \mathrm{O} 33$

Keywords: Input-output models; Geographical information system (GIS); Scenario analysis; China; Land use change

\section{Introduction}

Land availability is crucial for China's food security and economic development. Although China has a total area of some 960 million ha, which is the third largest in the world, only about $14.8 \%$ are cultivated with field crops and horticultural

\footnotetext{
* Corresponding author. Tel.: + 1-518-276-8088; fax: + 1-518-270-2235

E-mail address: klaus_hubacek@yahoo.com (K. Hubacek).
} 
products. Primary farmland is located mainly in the same geographic areas where population and major economic activities have been concentrated. About one billion people (out of China's population of 1.3 billion) are concentrated in less than one third of the land area. The eastern region (Yangtze Delta), Sichuan, and the urban conglomerations along the eastern coast are the main population centers. These coastal areas are also the ones experiencing the highest growth rates in the economy. In several eastern provinces, settlement areas cover already more than $10 \%$ of the total land and are further expanding. Cropland areas are shrinking due to both urban sprawl and growing land requirements of villages, rural industries, and infrastructure. On balance, China lost some 980000 ha of cultivated land to construction activities between 1988 and 1995 (Fischer et al., 1998).

China's food security can also be threatened by losses of cultivated land due to disasters, soil erosion, and chemical and physical deterioration. Agricultural overexploitation and industrial pollution also exacerbate these degradation problems. Although there have been controversies over the issues of food demand and supply in China for the next 30 years (Chen et al., 1996; Huang and Rozelle, 1997a), there appears an agreement that arable land loss and land degradation are undermining China's food production capacity (e.g. Gardner, 1996; Rozelle and Huang, 1997). In the case of forestland and grassland over-exploitation and degradation might be even more severe (Fischer et al., 1996; Liu, 1998).

Another trend in land use is agricultural restructuring represented by the transformation of cropland into horticultural land and fishponds. This is a rational response to changes in consumer demand and becomes also permitted by institutional and supply-side factors. It has become much more profitable for Chinese farmers to grow vegetables and fruit and sell these for market prices rather than to produce rice or wheat, which are still regulated by the state's procurement system. The conversion of cropland into fishponds and horticultural lands following the market-driven restructuring requirements of the agricultural sector would actually increase food security. The conversion of cropland into forest and grassland, according to the requirement of conserving soil resources and environment, is also desirable from a long-term perspective.

These changes in China's land use pattern reflect changes in the country's institutional framework, economy, and society. China has been in the transition from a command to a market economy since 1978, resulting in an annual real GDP growth rate of about $9.8 \%$ between 1978 and 1998. Increase in income combined with the migration from rural to urban areas has resulted in significant changes in lifestyles. These changes are compounded by China's large population.

In this study, we develop a number of scenarios around the major driving forces in China's economy and society, including technical change, income growth, changing pattern in consumption and production, urbanization, and population growth. The basic reference year is 1992 and the year for scenario analysis is 2025 . 
In order to assess how changes in the economy and society affect future land use, it is necessary to combine biophysical, economic, and societal data. A consistent theoretical framework is of fundamental importance for such investigations. In this paper, we employ a structural economics framework in which scenarios about possible future stages of society, economy, and the environment are embedded. The core of our framework is an input-output (I-O) model with strong biophysical linkages to allow the assessment of land use and land cover change. Socioeconomic changes are linked to different types of land via an explicit representation of land requirement coefficients associated with specific economic activities. In this way, land is treated as explicit factor input. The strong biophysical linkages are mainly manifested in the derivation of regional differences of the land requirement coefficients and the typical I-O technical coefficients. In other words, while we can stylize certain technological development trends at the national level based on a literature survey, their regionalization is not straightforward. We create the regionalized linkages based on the Agro-Ecological Zone (AEZ) assessment, a specialized tool based on a Geographical Information System (GIS). In addition, the AEZ assessment is also used to derive the future land suitability in each region.

In many studies dealing with similar questions, the focus has been either on a small region or on all of China. The small-region models might deliver excellent results for the region concerned, but they are unable to deal with the inter-play across regions and do not allow any predictions for the national level. Studies focussing on the national level usually lack the capability to tackle regional differences and the interaction among regions. Typically, population densities, soil and climate conditions, and economic development paces are significantly different across regions in a large developing country like China. China can be perceived as a group of co-evolving, disparate economies rather than a homogenous entity. On one hand, China has fast-developing urban growth centers in the coastal areas and, on the other hand, backward rural areas that are each associated with distinct income, lifestyle and expenditure patterns. Differing regional growth paths in the past might also have considerable path-dependent effects in the future and influence the future flow of regional migration due to labor demand of growth centers.

In this paper, we build our model from the ground up and develop seven regional models and then a national one for China. We specify various development paths for different regions using data and information available at both the regional and national level. Although each regional model is independently developed at the first glance, the combination of and communication between regional and national models enable us to investigate how the constraints of (immobile) land availability in each region might affect the inter-regional trade flow of land-based products. This further allows us to evaluate the degrees of land scarcity at both regional and national levels and the extent of the necessary land-productivity improvement that is desired for keeping the land requirement feasible in the future. As far as we know, our modeling is among the very first to set up inter-related regional I-O models for China with strong biophysical linkages explicitly focussing on land use change. 


\section{Linking the basic input-output model with biophysical data}

The core of our approach is an I-O model expanded by a set of land categories. The economy is represented by 11 sectors. The land-intensive agricultural sector is disaggregated into six sub-sectors. Other sectors include industry, construction, transportation, commerce, and services. Final use consists of five categories. They are urban and rural household consumption, respectively, government consumption, fixed investment and changes in inventory. The biophysical linkage between the economy and the changes in land use and land cover are represented by four land categories based on land use suitability classification.

The rationale why the standard $\mathrm{I}-\mathrm{O}$ framework can be extended to estimate land use change can be summarized as follows. In order for the final demand of a given sector to expand, the output of other sectors must expand in response to the input requirements of the given sector. Since all economic activities consume space, in the long-run, in order to achieve significant increases in output, there must be increases or changes in land use or land productivity.

In the standard version, changes in the exogenously given vector of final demand $(\Delta y)$ are driving the economy via a matrix of output multipliers, i.e., the Leontief inverse, $(I-A)^{-1}$, resulting in changes in sectoral output $(\Delta x)$ :

$$
(I-A)^{-1} \Delta y=\Delta x \text {. }
$$

In order to link land-use changes in economic sectors to those in land categories (such as cultivated land, grassland, forestland, etc.), the vector representing changes in output $(\Delta x)$ is pre-multiplied by a diagonal land requirement coefficient matrix $(\hat{C})$ and a land distribution matrix $(R)$. The land distribution matrix $R$ gives the mapping relationship between land uses in economic sectors and the natural categories of land cover, and the attributes in $R$ are the shares of the former in the latter. The land requirement coefficient vector $\left(c_{j}\right)$ is defined as the ratio of total land use in each sector $\left(L_{j}\right)$ over total sectoral output $\left(x_{j}\right)$, representing land use in hectares per one million Yuan of output of sector $j$. Coefficient $c_{j}$ is equivalent to the inverse of sectoral land productivity $\left(p_{j}\right)$, which represents the output in Yuan produced on 1 ha of land. The future land use $\left(L^{2025}\right)$ is the sum of the present land uses $\left(L^{1992}\right)$ and the changes in land use $(\Delta L)$ triggered by the changes in output $(\Delta x)$ as given in Eq. (1).

$$
\begin{aligned}
& \Delta L=R \hat{C} \Delta x, \\
& L^{2025}=L^{1992}+\Delta L .
\end{aligned}
$$

Standard I-O models usually assume that the economy instantaneously (i.e. within the given statistical year) adjusts to shifts in spending patterns. All production activities are assumed to be endogenous and demand-driven, due to the assumed excess capacity throughout the economy. Supply is assumed to be perfectly elastic in all sectors, and an increase in demand is sufficient to stimulate increases in output and incomes. In dealing with land use, however, clearly some sectors will not automatically expand or shrink their land requirements in direct proportion to 
output changes. For instance, they might be unable to do so because of zoning regulations or restrictions of land availability. If this is indeed the case, then the model derived above will provide multiplier estimates that are unrealistically large due to the simple assumption on supply response. A more reasonable assumption is that the availability of land restricts the production of goods and services. As a consequence, the standard I-O model needs to be modified to incorporate supply constraints on certain production activities, permitting a more realistic evaluation of multiplier effects of injections into the economy. To account for restrictions in supply a number of authors have developed models with supply assumed to be completely inelastic in some of the sectors (Lewis and Thorbecke, 1992; Miller and Blair, 1985; Parikh and Thorbecke, 1996; Subramanian and Sadoulet, 1990). The basic setup of these mixed models is given by:

$$
\left[\begin{array}{c}
X_{\mathrm{no}} \\
Y_{\mathrm{co}}
\end{array}\right]=\left[\begin{array}{cc}
P & 0 \\
R & -I
\end{array}\right]^{-1}\left[\begin{array}{ll}
I & Q \\
0 & S
\end{array}\right]\left[\begin{array}{l}
\bar{Y}_{\mathrm{no}} \\
\bar{X}_{\mathrm{co}}
\end{array}\right]
$$

where the sub-matrices are defined as follows. ${ }^{1}$

$P$ is the $k \times k$ matrix containing the elements from the first $k$ rows and the first $k$ columns in $(I-A)$, and represents average expenditure propensities of nonsupply constrained sectors. The sectors have been labeled so that the first $k$ sectors indicate the endogenous elements and the last $(n-k)$ sectors are the exogenous sectors.

$R$ is the $(n-k) \times k$ matrix containing elements from the last $(n-k)$ rows and the first $k$ columns of $(-A)$ and represents average expenditure propensities of non-supply constrained sectors on supply constrained sector output.

$X_{\text {no }}$ is the $k$-element column vector with elements $x_{1}$ through $x_{k}$; representing endogenous total output of non-supply constrained sectors.

$Y_{\text {co }}$ is the $(n-k)$-element column vector with elements $y_{k+1}$ through $y_{n}$, representing endogenous final demand of supply constrained sectors.

$Q$ is the $k \times(n-k)$ matrix of elements from the last $(n-k)$ rows and first $k$ columns of $(A)$ and represents supply constrained sector expenditure propensities on non-supply constrained sector output.

$S$ is the $(n-k) \times(n-k)$ matrix of elements from the last $(n-k)$ rows and columns of $-(I-A)$, and represents average expenditure propensities among supply constrained sectors.

$\bar{Y}_{\text {no }}$ is the $k$-element column vector of elements $y_{1}$ through $y_{k}$, representing exogenous final demand for non-supply constrained sectors.

$\bar{X}_{\text {no }}$ is the $(n-k)$-element column vector of elements $x_{k+1}$ through $x_{n}$, representing exogenous total output for supply constrained sectors.

In the modified model Eq. (3), changes in exogenous final demand for non-supply constrained sectors or changes in exogenous supply for the constrained sectors are met by changes in output for the unconstrained sectors and by changes in imports and exports for the constrained sectors.

\footnotetext{
${ }^{1}$ For the detailed derivation of the mixed model, see Miller and Blair (1985) pp. 326.
} 
In the empirical analysis, the major land-use sectors, including grains, other crops, forestry, and livestock, are treated as the supply constrained sectors. The implicit assumption is that the non-agricultural sectors such as industry and services enjoy better chance in appropriating the necessary land and are often able to expand their production activities to previous cropland, forestland or grassland.

The derived potential net export of the products of supply-constrained sectors $(T)$ are the difference between the exogenous and endogenous final demand in the corresponding sectors:

$$
T=\bar{Y}_{\mathrm{co}}-Y_{\mathrm{co}} .
$$

Exogenously generated potential output $\left(x_{f}\right)$ is obtained through dividing the land per land-use category available in $2025\left(\bar{L}_{\mathrm{f}}\right)$ by the respective future land requirement coefficient $\left(c_{\mathrm{f}}\right)$ :

$$
x_{\mathrm{f}}=\frac{\bar{L}_{\mathrm{f}}}{c_{\mathrm{f}}} .
$$

The AEZ assessment model is used to derive regional differences for the land requirement and land productivity coefficients, to disaggregate the agricultural sectors into six sub-sectors in each regional I-O models, to calculate exogenously generated potential output, and to quantify the availability of land under different technical assumptions.

The AEZ method was developed by IIASA and FAO (FAO, 1995). It was repeatedly used and subsequently improved in several global and national studies (FAO/IIASA, 1993; Fischer and Makowski, 2000). A detailed presentation of all functions of AEZ modeling is beyond the scope of this paper. ${ }^{2}$ To understand the basic principles of the AEZ approach, let us consider an illustrative example. A farmer faces the task to evaluate the suitability of a particular land unit for crop production. The farmer would take into consideration a whole range of factors, including the quality of soil, the local climate conditions, and the possibilities of using different types of inputs such as fertilizers, pesticides, machinery, etc. The farmer would also consider various mixes of crops that are possible under the specific conditions of this plot, including multiple sequential cropping. The AEZ algorithm proceeds in a similar way and incorporates more well-established scientific information in a geographical information system. It calculates attainable yields of each grid-cell on the given digital maps through suitability assessment. An $\mathrm{AEZ}$ is a polygon obtained by overlaying maps of the climatic resources inventory (i.e. map of climatic belt, thermal zone, length of growing period), with maps of soil resources inventory and terrene conditions. Each AEZ land unit is then assessed in terms of all feasible agricultural land use options that are of interest. At a given level of input, the productivity assessment records expected production of relevant agro-ecologically feasible agricultural activities.

\footnotetext{
${ }^{2}$ For a description of a global-scale AEZ application consult http://www.iiasa.ac.at/Research/LUC/ GAEZ.
} 
The strength of the AEZ method is manifested in its ability to match land quality with the ecological requirements of the respective plants for soils, climates, etc. under explicit recognition of the socio-economic settings. The application of this method allows us to calculate this part of regional differences that is basically determined by natural factors. In addition, technical change can be explicitly incorporated in the analysis through the establishment of various input levels. We apply the results of the AEZ assessment to the sectors of grains, other crops, and pasture livestock production. Due to the fact that land suitability changes along with changes in management intensities and socioeconomic conditions, three production scenarios for low, medium, and high input levels are developed (see e.g. Xie and Jia, 1994). Variations in input levels are represented by the differences in multi-cropping indexes, scale and intensity of land management, factor-intensity of labor, capital, and energy utilization, and operational technologies employed.

\section{Representation of the regional economies and their land bases}

\subsection{Re-establishment of regional input-output tables}

In our I-O model, China is divided into eight regions based on their respective geographic, agro-climatic, and demographic features, and economic development levels. The regional map is consolidated with provincial level administrative boundaries for the sake of data availability and consistency. The map of these eight regions is presented in Fig. 1.

Seven out of the eight regions form the geographic building block in the I-O model. The Plateau region is not considered because of a lack of I-O data.

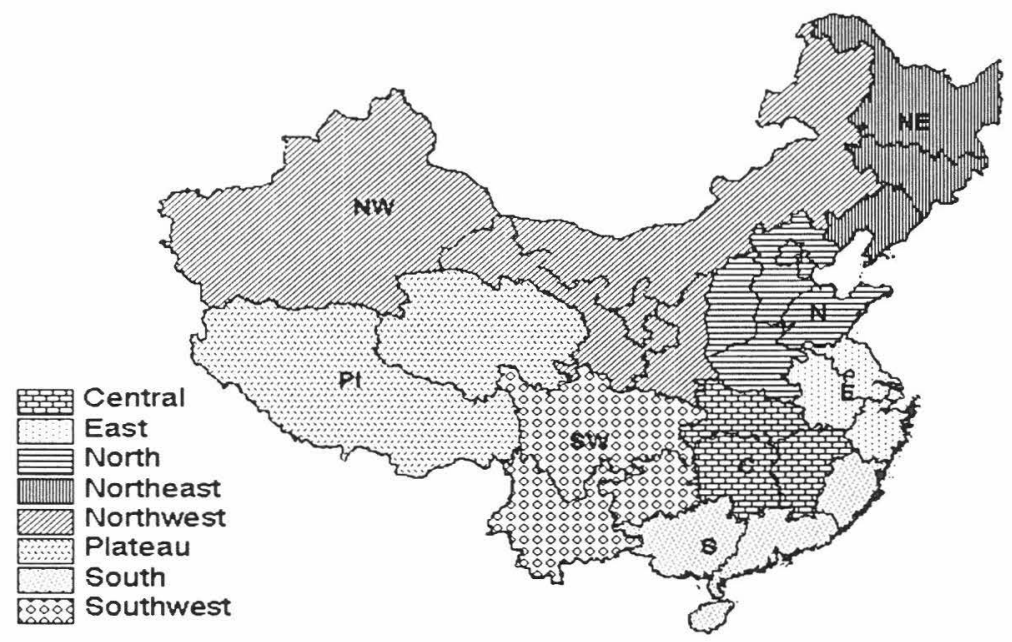

Fig. 1. Map of China with provincial bounaries and the eight economic regions. Note: Taiwan is not included in this analysis thus in the map. 
Table 1

Scheme of the regional input-output table and the available data for 1992

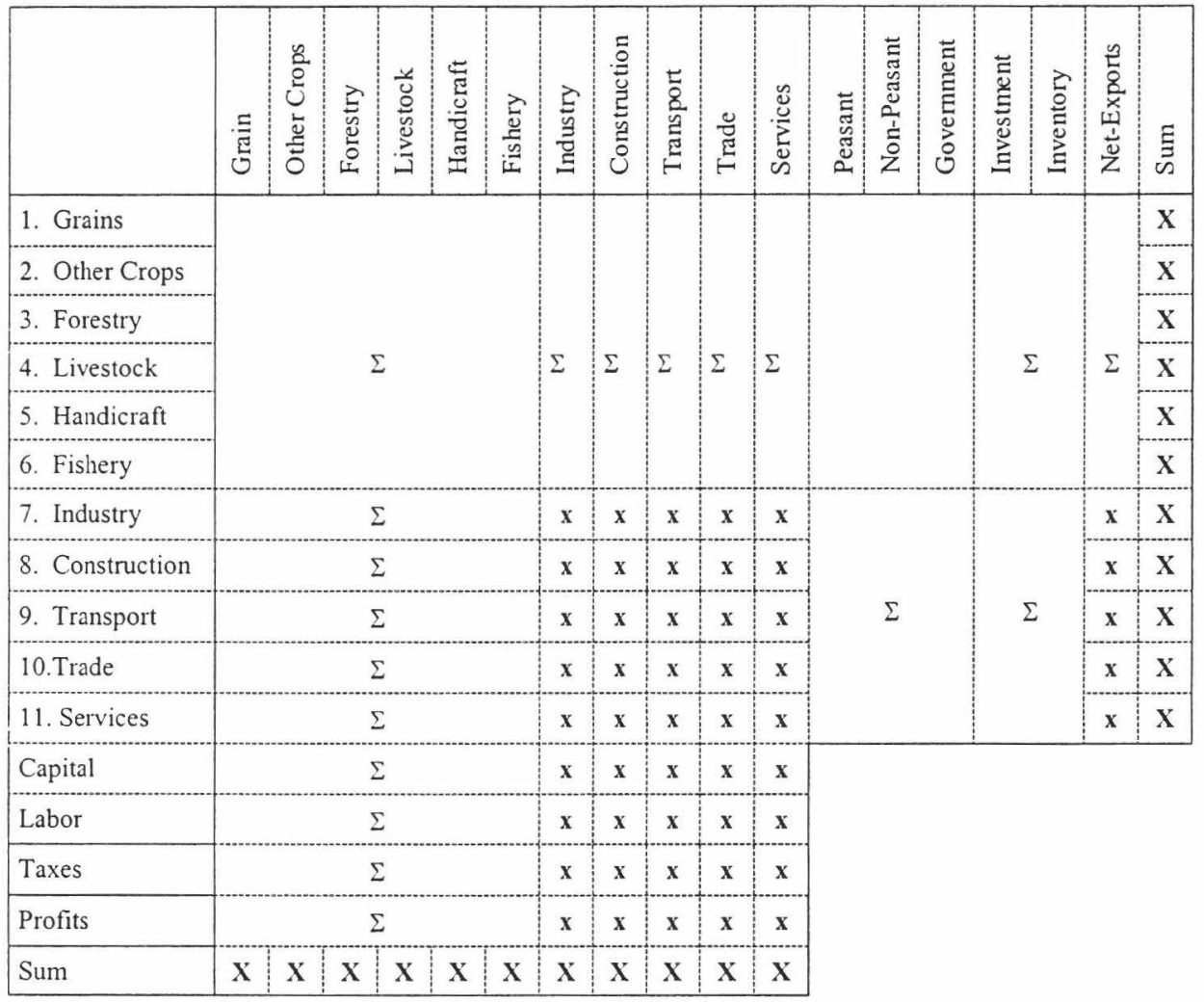

Notes: $X$ indicates data available from statistical yearbooks and regional input-output tables. $\Sigma$ indicates that only aggregate information for a group of cells are available. Sources: Statistical Yearbook of Rural China (State Statistical Bureau, 1993, pp.59-60), Statistical Yearbook of China (State Statistical Bureau, 1993, pp.47 and 49), and regional I-O tables.

Although it holds strategic importance in terms of geography and politics, its shares in terms of economic output, fertile land, and population are minor in comparison to those of the other regions.

The economies of China and its regions in 1992 are represented by the 1992 I-O tables. These tables were constructed by the State Statistical Bureau of China (SSB) (State Statistical Bureau of China 1996, 1997). The national table includes 118 sectors, with six agricultural sectors. The regional tables are in a more aggregate form with only one agricultural sector (see Table 1). The 'value-added' in all tables consists of four categories - capital depreciation, labor compensation, taxes, and profits. 'Final use' in the national table comprises of six categories-peasant, non-peasant, and government consumption, fixed investment, inventory changes, and net exports. The regional table gives only three final use categories-total consumption, total investment, and net exports. 
For the purpose of analyzing land use and land cover changes at the regional level, we re-establish the regional $\mathrm{I}-\mathrm{O}$ tables by disaggregating the agricultural sector into six sub-sectors, distinguishing total consumption into peasant, non-peasant, and government consumption, and separating fixed investment from changes in inventory. We further assume that peasant consumption is similar to rural consumption and non-peasant consumption assembles the consumption pattern of urban people. ${ }^{3}$

Techniques used in the re-establishment can be summarized as follows. We first apply a procedure based on adjustment of national coefficients using the techniques of location quotients (LQs) adjustments (Mayer and Pleeter, 1975; Miller and Blair, 1985; Flegg et al., 1995). Then, we minimize the sum of squares of the percentage difference between the unknown cell figures and those obtained from the LQs procedure for each regional table, subject to the typical I-O balancing condition and other given sum requirements (for more detail see Sun, 2000).

\subsection{Projections of future technology}

The impact of changes in economy and society on land use and land cover will be dictated by the future patterns of both consumption and production. The possible future patterns of consumption are discussed in the form of various scenarios in Section 4. The patterns of production are represented in the technology matrix or $A$-matrix. Their immediate effects on land use are represented in the land-requirement coefficients or $C$-matrix (see Eq. (2a)). To project the future production functions for each of the respective sectors, we use a mixed approach of applying case studies and the RAS method. ${ }^{4}$ We use the case studies for projecting key cells of the future production functions of certain sectors, as indicated by ' $\mathrm{B}$ ' in Table 2. Then we calculate the missing cells based on information indicated in Table 1 and by using the RAS method (Budavari, 1981, p.404, Miller and Blair, 1985).

The case study methodology, suggested and applied by Duchin and Lange (Duchin et al., 1993; Duchin and Lange, 1992, 1994), represents a set of guidelines and principles for a systematic approach to construct I-O matrices from technical data. The purpose of this approach is to develop a number of scenarios about the future regarding certain key economic sectors in terms of growth and technologies

\footnotetext{
${ }^{3}$ There are gross inconsistencies in the SSB-classification system for urban, rural, and city population, because the system mixes territorial and functional definitions. The definitions have also been changed over time and non-recorded migration from rural to urban areas further distorts the actual residency (Heilig, 1999).

${ }^{4}$ The term RAS refers to a mathematical procedure for adjusting, sequentially, rows and columns of a given input-output coefficient matrix, $A(0)$, in order to generate an estimate of a more recent matrix, $A(1)$, when only the new structural information of sectoral output, $X(1)$, intermediate deliveries, $U(1)$, and intermediate purchases, $V(1)$, are assumed known. Once the procedure converges, the final outcome used to be denoted as $A(1)=R A(0) S$, in which $R$ is a diagonal matrix that is the product of a series of diagonal matrices, and so is $S$.
} 
and to construct a corresponding database that contains the quantification of these parameters (Idenburg, 1993, pp.35). The development of such case studies requires assembling information from many sources, such as technical publications and databases, and expert opinions. Although a full implementation of this approach is usually difficult to achieve due to research cost constraint and the difficulties involved in coordinating widely diverse engineering assumptions, its methodological principles provide structure and discipline. It forces the user to make all assumptions explicit, which makes it easier for others to use and to evaluate the results of the case studies. In our case, we develop case studies for the key-cells of the $A$-matrix for 2025. We focus on the linkages between the economy and the biophysical realities based on different technology assumptions, and also pay a

Table 2

Scheme of input-output table of China in 2025

\begin{tabular}{|c|c|c|c|c|c|c|c|c|c|c|c|c|c|c|}
\hline & 胥 & $\begin{array}{l}\frac{8}{2} \\
0 \\
\frac{5}{2} \\
0\end{array}$ & 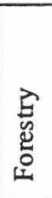 & 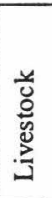 & 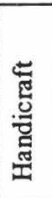 & 蛋 & 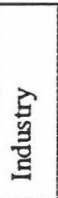 & 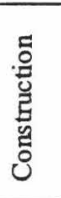 & 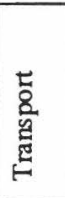 & 莺 & 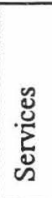 & 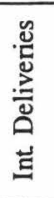 & 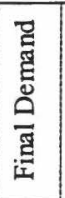 & $\frac{0}{0}$ \\
\hline 1. Grains & & & & B & & & B & & & & & $\mathbf{U}$ & FD & $\mathrm{x}$ \\
\hline 2. Other Crops & & & & & & & & & & & & $\mathbf{U}$ & FD & $\mathrm{x}$ \\
\hline 3. Forestry & & & & & & & & & & & & $\mathbf{U}$ & FD & $\mathbf{x}$ \\
\hline 4. Livestock & & & & & & & & & & & & $\mathbf{U}$ & FD & $\mathrm{x}$ \\
\hline 5. Handicraft & & & & & & & & & & & & $\mathbf{U}$ & FD & $\mathbf{x}$ \\
\hline 6. Fishery & & & & & & & & & & & & $\mathbf{U}$ & FD & $\mathrm{x}$ \\
\hline 7. Industry & & & & B & & & & & & & & $\mathbf{U}$ & FD & $\mathbf{x}$ \\
\hline 8. Construction & & & & & & & & & & & & $\mathbf{U}$ & FD & $\mathrm{x}$ \\
\hline 9. Transport & & & & & & & & & & & & $\mathbf{U}$ & FD & $\mathrm{x}$ \\
\hline 10. Trade & & & & & & & & & & & & $\mathbf{U}$ & FD & $\mathrm{x}$ \\
\hline 11. Services & & & & & & & & & & & & $\mathrm{U}$ & FD & $\mathbf{x}$ \\
\hline Intermediate Purchases & v & $\mathbf{v}$ & v & $\mathbf{v}$ & v & $\mathbf{v}$ & v & $\mathbf{v}$ & $\mathbf{v}$ & $\mathbf{v}$ & $\mathbf{v}$ & & & \\
\hline Value Added & \multicolumn{11}{|c|}{$x-v$} & & & \\
\hline Total Output & $\mathbf{x}$ & $\mathbf{x}$ & $\mathbf{x}$ & $\mathbf{x}$ & $\mathbf{x}$ & $\mathbf{x}$ & $\mathbf{x}$ & $\mathbf{x}$ & $\mathbf{x}$ & $\mathbf{x}$ & $\mathbf{x}$ & & & \\
\hline Land in Yuan/ha & $\mathbf{L}$ & $\mathbf{L}$ & $\mathbf{L}$ & $\mathbf{L}$ & $L$ & $\mathbf{L}$ & $L$ & $\mathbf{L}$ & $\mathbf{L}$ & $L$ & $\mathbf{L}$ & & & \\
\hline
\end{tabular}

Notes: $L$ 's are derived from literature and the AEZ model. $U$ 's, $V$ 's, and $X$ 's are derived for the major economic sectoral groups of agriculture, industry, and services from World Bank estimates and by comparison to structural changes in industrialized countries over a longer time period. Sub-sectoral shares within the agricultural sector are derived from an AEZ-based scenario assessment. B's are subject to a restricted lower-bound in the optimization procedure, respectively, so as to guarantee a sufficiently high figure in the corresponding cell, which would partly reflect the increasing share of feeding mode in livestock production. 
Table 3

Land requirement coefficients for China's regions in 1992 and 2025 (ha per million Yuan)

\begin{tabular}{|c|c|c|c|c|c|c|c|c|}
\hline \multirow[t]{2}{*}{ Economic Regions } & \multicolumn{2}{|c|}{ Grains } & \multicolumn{2}{|c|}{ Other Crops } & \multicolumn{2}{|c|}{ Forestry } & \multicolumn{2}{|l|}{ Livestock } \\
\hline & 1992 & 2005 & 1992 & 2005 & 1992 & 2005 & 1992 & 2005 \\
\hline R1-North & 363.8 & 178.3 & 145.0 & 102.6 & 510.7 & 382.99 & 104.7 & 330.2 \\
\hline R2-Northeast & 513.3 & 249.5 & 169.5 & 75.0 & 8663.3 & 6497.48 & 353.2 & 1132.4 \\
\hline R3-East & 236.8 & 366.5 & 103.1 & 83.5 & 730.7 & 548.00 & 12.6 & 39.9 \\
\hline R4-Central & 231.9 & 183.1 & 105.1 & 64.9 & 1438.8 & 1079.10 & 136.2 & 434.7 \\
\hline R5-South & 326.6 & 226.7 & 76.4 & 50.6 & 1112.0 & 833.97 & 141.8 & 443.9 \\
\hline R6-Southwest & 450.1 & 329.5 & 149.8 & 110.0 & 2599.3 & 1949.45 & 752.0 & 2303.0 \\
\hline R7-Northwest & 786.5 & 517.5 & 233.7 & 154.7 & 5387.5 & 4040.62 & 17774.6 & 24608.5 \\
\hline China & 391.3 & 281.8 & 130.9 & 101.0 & 2088.9 & 1566.69 & 2661.8 & 2928.0 \\
\hline
\end{tabular}

Sources: references in Section 4.4. Procurement prices for grains and other crops in 1992 (Price Statistical Yearbook of China 1992pp.302-334) are used for value aggregation. Assessment of crop production potential is taken from Xie and Jia (1994). Regional variations of livestock production are based on Zheng and Tang (1994).

special attention on the future grain input requirements of the livestock sector. The remaining missing data are estimated by the RAS procedure.

\subsection{Projection of future land availability}

The I-O model is extended to incorporate land use. The land use data is derived from the IIASA-LUC database. A number of fairly large and detailed geographical databases on China, including biophysical attributes of land and statistical data at the county level, have been implemented in the LUC geographical information system. These data sets allow us to estimate the land acreage used in each of the economic sectors.

These data, together with those provided by the I-O tables, allows us to calculate land requirement coefficients for the base year as explained in Section 2. The current land requirement coefficients shown in Table 3 represent the reciprocals of the average productivity of the total acreage in a given land use category. The use of these coefficients in scenario analysis would give us the land requirement at present-day efficiency. The higher the number in each cell the less productive is the land to produce the respective output. The huge variability of coefficients for livestock production is partly due to the varying shares of pasture versus farmbased livestock production across regions, and partly due to the different environmental factors such as soil, temperature, and precipitation, which influence grassland productivity significantly.

Land availability forms a binding constraint to land-use requirements in general and to agricultural land uses in particular. Without additional available land, the only choice left for an economy is either to increase land productivity or increase imports. Given the foreseen scenarios of land productivity improvement and land availability, the balancing of the $\mathrm{I}-\mathrm{O}$ model will give the required net import of 
land-based sectors so as to meet the additional final demand created by changes in the economy and society.

For the calculation of future land requirements per land cover category, we need a land distribution matrix ( $R$ in Eq. (3)) as shown in Table 4. This matrix establishes the linkage between land-uses by economic sectors and the categories of land cover. The entries in Table 4 are numbers between 0 and 1, which indicate the percentage distribution of land used by economic sector in each of the major land categories. The numbers do not represent current patterns of land use and land cover but rather their future development. As the table shows, various land-use options, such as residential land, industrial land, horticulture, and fish, compete for cultivated land, grassland, and forestland. The category of unused land or multiple uses represents a residual value. In the case of fish production, for example, part of it is farmed on agricultural land without diminishing the usage of agriculture land. Such kind of multiple uses do not decrease the ability to use land for other production purposes.

The expansion of built-up land is assumed to be a result of expanding on previously unused land and the continuous land conversion from agricultural uses to higher value-added non-agricultural and residential uses. This expansion will take place mainly around economic centers. To capture it, we employ GIS software tools (Arc-Info). By overlapping the map showing existing agglomeration with the map containing current land uses, agglomerations are expanded by adding an additional ring of a certain width to the outskirts of each existing built-up area. The determination of this width is based on the scenarios of future demand for residential and non-agricultural uses of lands. In this way, we can see how the expansion of existing built-up areas reduces the amount of other land cover categories as shown in Fig. 2. To receive the land area available in 2025, we deduct land requirements for additional built-up land from the three major land categories and assume that the share of cultivated land used for other crops will increase by

Table 4

Land distribution matrix in 2025

\begin{tabular}{llllllll}
\hline $\begin{array}{l}\text { Economic } \\
\text { sectors }\end{array}$ & \multicolumn{6}{l}{ Major land cover categories } \\
\cline { 2 - 7 } & Grains & Other Crops & Forestland & Grassland & Water Areas & Unused & Sum \\
\hline Grains & 1 & 0 & 0 & 0 & 0 & 0 & 1.00 \\
Other crops & 0 & 1 & 0 & 0 & 0 & 0 & 1.00 \\
Forestry & 0 & 0 & 1 & 0 & 0 & 0 & 1.00 \\
Livestock & 0 & 0 & 0 & 1 & 0 & 0 & 1.00 \\
Fishery & 0.10 & 0 & 0 & 0 & 0.89 & 0.01 & 1.00 \\
Developed $^{a}$ & 0.61 & 0.11 & 0.13 & 0.07 & 0.07 & 0.08 & 1.00 \\
\hline
\end{tabular}

\footnotetext{
a The category 'Developed' includes residential land, infrastructures, and industrial and commercial uses.

Source: based on scenarios in a GIS environment: expansion of existing agglomerations by adding an additional ring of one kilometer width, to the outskirts of each existing built-up area.
} 


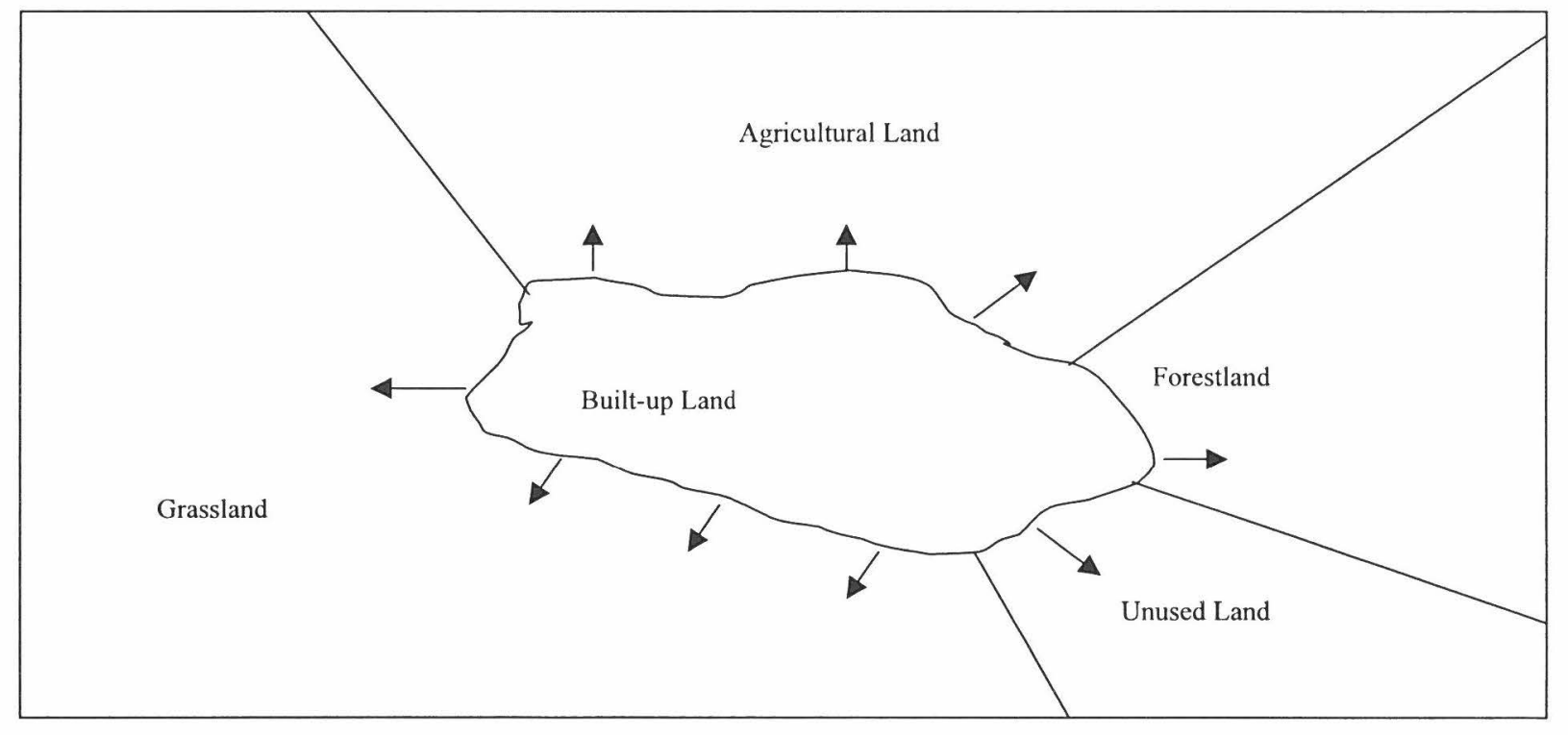

Fig. 2. Scheme of extension of built up land in a GIS scenario. Notes: the existing areas are captures with remote sensing. Unfortunately, this method only recognizes built-up areas beyond a certain size. As a consequence, the so-derived land conversions reflect only the extension of larger agglomerations. 
about 6 percentage points between 1992 and 2025 (following the trends of the last decade); we further assume that land losses due to erosion could be fully compensated by reclamation.

\section{Driving forces of land use change}

During the post-reform economic growth period after 1978, China has experienced a dramatic loss of arable land. Research has shown that both industrialization and land degradation have played an equally important role in reducing the total acreage of arable land (Sun and Li, 1997). Due to the dynamic changes in economy and society further losses of cropland are expected for the coming decades. For a comprehensive understanding of the future land use dynamics, we have identified a number of major driving forces represented by six scenarios (see the lower part of Fig. 3).

After establishing scenarios for each of the major driving forces, we introduce them step by step to show the additional effects. Starting from the base year reality, a set of scenarios representing each of the major factors is added to show its additional effects on land requirements. Scenario A represents the real situation in the base year 1992, with the technology and population level, share of urban and rural population, consumption pattern, and economic structure of 1992 . Scenario B applies plausible technology available in year 2025 to the socioeconomic and demographic structure of 1992. In Scenario C, we add to Scenario B final demand changes and additional direct land requirements caused by a population of 1.49 billion people. Scenario D includes per capita income growth, as well as lifestyle changes as represented by a set of income elasticities. Scenario E deals with the aggregate effects of Scenario D plus urbanization. Scenario F is designed to see the overall effects of a higher population estimate of 1.55 billion people and a higher share of urbanization combined with Scenario E.

\subsection{Economic growth and the consequent per capita income growth}

Since 1978, China's GDP has expanded at an average rate of nearly $10 \%$ and total exports at 17\% per year. The Fifteen-Year Perspective Plan (1995-2010) identifies two fundamental transitions to sustain future growth: (1) from a traditional planned economy to a socialist market economy; and (2) from the extensive growth path, based on increases in inputs, to an intensive growth fashion, driven by improvements in efficiency. Measures to sustain further growth include the restructuring of large state-owned enterprises, promoting science and technology, developing machinery, electronics, petrochemicals, automobiles, and construction as the pillar industries, and stimulating the growth of basic agricultural products, especially grain, cotton, and oilseed (World Bank, 1997b). Assuming the continuance of high saving rates supporting high investment rates, of the market-oriented reforms, and of high factor productivity growth, the World Bank projected growth rates of annually $6.6 \%$ until 2020 . The projections for individual sectors are ranging from 


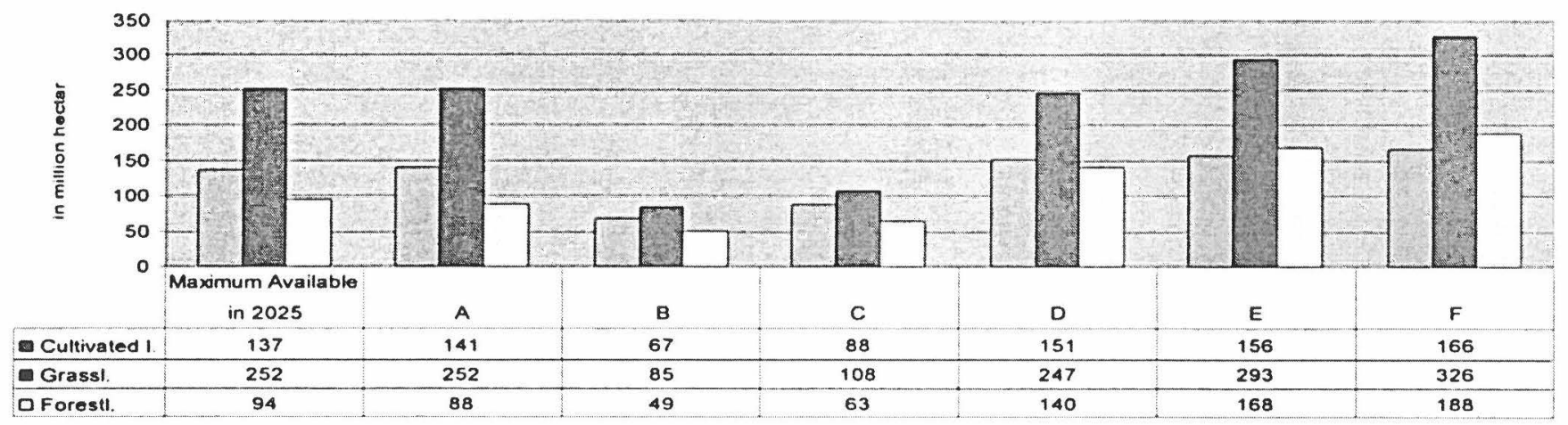

\begin{tabular}{|c|c|c|c|c|c|c|}
\hline \multirow[b]{2}{*}{$\begin{array}{c}\text { Major } \\
\text { Driving Forces }\end{array}$} & \multicolumn{6}{|c|}{ Scenarios } \\
\hline & $\begin{array}{c}A \\
\text { (China1992) }\end{array}$ & $\begin{array}{c}\mathbf{B} \\
(A+\text { Technolog })\end{array}$ & $\begin{array}{c}\mathrm{C} \\
(\mathrm{B}+\text { Population })\end{array}$ & $\begin{array}{c}\text { D } \\
\text { (C + Income } \\
\text { Growth) }\end{array}$ & $\begin{array}{c}\mathbf{E} \\
\text { (D+ Urbanization) }\end{array}$ & 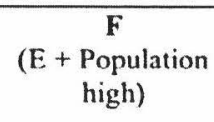 \\
\hline ical Level & 1992 & 2025 & 2025 & 2025 & 2025 & 2025 \\
\hline (in billions) & 1.171 & 1.171 & 1.49 & 1.49 & 1.49 & 1.55 \\
\hline vel & 1992 & 1992 & 1992 & 2025 & 2025 & 2025 \\
\hline ion Level & 1992 & 1992 & 1992 & 1992 & 2025 & $2025^{\star}$ \\
\hline
\end{tabular}

Fig. 3. Land requirements of different scenarios. Notes:* Higher urbanization rate of 59\% for 2025 (Shen and Spence, 1996). Main assumptions: B: A + Annual land productivity gains of $1,0.98$ and $0.68 \%$ for cropping, livestock, and forestry, respectively. C: B + population of 1.49 billion. D: $\mathrm{C}+4.2-5.7 \%$ average annual growth rate per capita income with the associated income elasticities (thus lifestyle). E: D $+50 \%$ urban population with the associated expenditure patterns. F: E with population of 1.55 billion. Urban and rural infrastructure, residential land, and services are linked to a set of land per capita ratios, industrial land is assumed to stay constant. In all of the scenarios, trade balances of land intensive products are kept proportional to today's imports and exports. 
$3.8 \%$ for agricultural sectors, $6.6 \%$ for industrial sectors, to $7.6 \%$ for service sectors (World Bank, 1997b, pp.21). According to the World Bank, the pace of GDP growth will be slowing down over time, from some $8 \%$ of today to $5 \%$ in 2020 due to a then stagnating labor force, diminishing marginal returns, and lower gains from structural change.

These aggregate growth trends mask diverging paths for different parts of China. There is a large body of literature dealing with the regional disparity in China (see for example Liu et al., 1999). It is generally acknowledged that three regions have emerged with discerned development paths in the past two more decades: (1) the leading coastal areas characterized by high income level and high growth rate; (2) the catching up central regions with average income level but rapid structural changes from agriculture to industry and services; and (3) the backward regions in the west, with a much slower growth rate, and with a small share of the population dominated by national minorities. Another significant disparity exists between rural and urban areas. The per capita income ratio of rural to urban residents has been around $1: 2.5$ in the past two decades.

GDP growth rate is a comprehensive indicator that is not independent of population growth (implying labor force growth) and technological progress. To make income growth rate be independent of other driving forces, we subtract the foreseen growth rate of population and the part corresponding to technological progress (about 35\% of GDP growth) from the predicted national GDP growth rate (World Bank, 1992, 1997b). As a result, we obtained a net per capita income growth rate. For simplicity, we call it per capita income growth rate. In order to accommodate to the regional and rural versus urban differences discussed above, we distinguish growth rates for urban and rural areas and for two large development zones.

\subsection{Population dynamics and urbanization}

When the People's Republic was founded in 1949, it had a population of 540 million; three decades later its population was more than 800 million; and present China's population has approached 1.3 billion. Today's high share of young Chinese in reproduction age has created a strong population momentum that is now driving China's population growth despite already low levels of fertility. China is confronted with two counteracting trends: while economic growth, urbanization and the associated lifestyle change may lead to lower fertility rates, modernization and the opening of society might lead to opposition to the government's strict one-child policy in family planning (Heilig, 1999). In its most recent (medium variant) projection, the UN Population Division estimates that China's population will increase to 1.49 billion in 2025 and then slightly decline to 1.488 billion in 2050 (United Nations Population Division, 1998). A somewhat higher projection estimates 1.55 billion people for 2025 (Shen and Spence, 1996).

A crucial characteristic of China's demographic situation is the concentration of its large population in the eastern part of the country. A large part of China's land is virtually uninhabited, such as the Gobi Desert, the steep slopes of the Himalayas, 
and the vast dry grasslands of the north-central region. Roughly 1.1 billion people (or about $90 \%$ of the population) live in only a little more than $30 \%$ of China's land area. The skewed spatial distribution of the population is a consequence of the country's uneven distribution of agro-climatic and biophysical environments, as well as the uneven development pace of industrialization.

In the past two decades, two opposite trends have coexisted to shape the population dynamics across regions. On one hand, migration from Western and Central China to the eastern regions, especially the coastal areas, adds percentage points to population shares of the eastern regions. However, on the other hand, the fertility rates moving upward from the eastern to the western regions have basically counter-balanced, if not exceeded, the impact of migration (Jiang and Zhang, 1998). In addition one has to consider the moving of traditional industries, particularly, heavy industry, from the eastern regions inward to the western regions and the new strategic movement of the Chinese government to reduce regional disparity. As a comprehensive result of these three trends, the accumulative impact of migration on regional population distribution up to 2025 may not be very significant. We assume that the population shares of East and South Regions, the most developed regions, in the national total will increase by one percentage point; the population shares of Central and Southwest Regions, the regions with high population density and the highest proportion of agricultural population, will decrease by one percentage point; and the population shares of other regions will stay unchanged.

Despite the fact that the urban population is constantly increasing, China can still be considered a predominantly rural society. In 1997, after the rapid increase of the officially defined urban population for more than a decade, only some $30 \%$ of the population lived in urban areas. The rather recent increase in urban population is mainly due to the promotion of towns into cities, thus increasing the number of cities altogether. Another reason for the increase in urban population has been the loosening of strictly controlled internal migration to meet the labor demand of the growing cities and towns. In addition, in recent years, there has been a wave of temporary 'illegal' rural-urban labor migration, called the 'floating population'. Some estimation puts the number of the floating population in large cities as large as being equal to $25 \%$ of the urban population (Heilig, 1999). We assume that this urbanization trend will continue in the future and that by 2025 about $50 \%$ of the Chinese population would live in urban areas. This assumption is consistent with the corresponding UN projection (United Nations Population Division, 1998). We further assume that agricultural population living in cities and towns will gradually adopt urban lifestyles.

There are no reliable estimates of the urbanization rate for different regions, since even present data on city growth and rural-urban migration is in poor quality. However, as we discussed in the previous sub-section, two large zones can be distinguished due to the striking development disparity between them. For the more developed eastern zone (regions R1-R5), we assume urbanization rates of roughly $54 \%$, and for the less developed western zone (regions R6 and R7), about 44\%, respectively. 


\subsection{Change in consumption pattern}

With respect to changes in consumption patterns, changes in diet structure are the most relevant to the study of land use change. In China's food tradition, cereal products have been of overriding importance; other food products such as meat, fishery products, vegetables, and fruit played only a residual role. This pattern has been changing due to recent social and economic developments. Urban residents typically prefer a more diverse diet and eat more processed foods. Today's Chinese eat more meat and dairy products, which has boosted livestock production. China's population has enormously increased its meat consumption and also eats more fruits and vegetables, whereas direct consumption of grain has leveled off or even declined (Wu and Findlay, 1997, pp.49). Despite these developments, China's average food calorie supply per person per day is still below the average level of developed countries (FAOSTAT, 1998). Therefore, an increase in per capita calorie consumption can be expected in the future.

A comparison of per capita calorie intake across some representative countries shows that today's food calorie supply of animal products in China is about 467 kcal per person compared with 503 in South Korea, $600 \mathrm{kcal}$ in Japan, and 1006 in USA. The average consumption for developed country is $867 \mathrm{kcal}$. In addition, today's calorie intake of fish in China is behind other Asian countries. Currently, food calorie supply of fish in China is $29 \mathrm{kcal}$, compared with $92 \mathrm{kcal}$ in South Korea and 194 kcal in Japan (FAOSTAT, 1998).

To incorporate these considerations in a consistent way and in line with our I-O modeling, we establish the scenarios of income elasticities for two periods, 1992 2005 versus 2005-2025, as presented in Table 5. The combination of scenarios of per capita income growth with income elasticities gives the scenarios of per capita expenditure pattern for the year 2025 .

To calculate aggregate final demand from households for the products of each production sector, we multiply the above-listed average expenditures of urban and rural residents, respectively, by the total numbers of urban or rural residents in each region. To obtain total final demand corresponding to each production sector, we link other final demand components to household consumption according to their current ratio to the level of aggregate household consumption.

\subsection{Technical change and land productivity}

China's economic success has been accommodated by enormous productivity gains. Yet China's economy can be still characterized by substantial inefficiencies and backward technologies and, therefore has enormous possibilities for improvements. The World Bank, (World Bank, 1997b, pp.20) estimated that an annual growth rate of total factor productivity of 5-7\% during 1995-2020 will lead to major changes in the relative size of economic sectors in terms of both output and labor force. For example, agricultural employment is expected to fall from more than half of total employment today to one-quarter within the next 25 years. 
Table 5

Change in consumption pattern and income elasticities

\begin{tabular}{|c|c|c|c|c|c|c|c|c|}
\hline \multirow[t]{3}{*}{ Sectors } & \multirow{2}{*}{\multicolumn{2}{|c|}{$\begin{array}{l}\text { Per capita expenditures (in Yuan) } \\
1992\end{array}$}} & \multicolumn{4}{|c|}{ Income elasticities for the period $1992-2025^{a}$} & \multirow{2}{*}{\multicolumn{2}{|c|}{$\frac{\text { Per capita expenditures (in Yuan) }}{2025}$}} \\
\hline & & & \multicolumn{2}{|c|}{$1992-2005$} & \multicolumn{2}{|c|}{$2005-2025$} & & \\
\hline & Rural & Urban & Rural & Urban & Rural & Urban & Rural & Urban \\
\hline Grains & 112.3 & $10.8^{\mathrm{c}}$ & 0.250 & 0.150 & 0.100 & -0.03 & 135.9 & 11.5 \\
\hline Other crops & 69.2 & 147.3 & 0.435 & 0.450 & 0.450 & 0.470 & 109.8 & 248.4 \\
\hline Forestry & 3.2 & 6.0 & 0.757 & 0.835 & 0.600 & 0.650 & 6.0 & 12.5 \\
\hline Livestock & 112.5 & 184.2 & 0.757 & 0.835 & 0.650 & 0.700 & 215.3 & 390.2 \\
\hline Handicraft & 13.8 & 29.6 & 1.100 & 1.100 & 1.100 & 1.100 & 33.9 & 78.0 \\
\hline Fish & 19.8 & 58.5 & 1.244 & 1.290 & 1.244 & 1.290 & 52.4 & 170.7 \\
\hline Industry & 306.0 & 887.4 & 1.100 & 1.100 & 1.100 & 1.100 & 750.3 & 2336.9 \\
\hline Construction & 44.0 & 115.1 & 1.100 & 1.100 & 1.100 & 1.100 & 107.8 & 303.2 \\
\hline Transportation & 4.9 & 19.2 & 1.200 & 1.200 & 1.200 & 1.200 & 12.5 & 53.3 \\
\hline Commerce & 65.5 & 197.0 & 1.200 & 1.200 & 1.200 & 1.200 & 169.3 & 548.2 \\
\hline Services & 67.7 & 278.8 & 1.200 & 1.200 & 1.200 & 1.200 & 174.8 & 775.7 \\
\hline Sum & 819.0 & 1934.0 & & & & & 1768.2 & 4929.5 \\
\hline
\end{tabular}

a Income elasticities are based on the estimates and calibrations in Huang and Rozelle (1998) and Huang and Chen (1999), and on our own adjustments

b The calculation of household expenditure in 2025 is based on following equation:

$E X(2025)=\left(1+\varepsilon \times \frac{I N(2025)-I N(1992)}{I N(1992)}\right) \times E X(1992)$

where $I N$ stands for Income and $E X$ for Expenditure in the respective years, and $\varepsilon$ represents income elasticities.

c This figure represents the direct purchase from the grain sector by urban residents (typically via free markets). Purchases of processed foods from the industrial, commerce, and service sectors are incorporated in expenditure figures in these sectors, respectively, following the input-output setup of China. 
These structural changes will have considerable effects on the structure of land use. Most important for our assessment of the future land-use change are technical changes and productivity gains in the primary sectors. In grain production, average yields in China are generally higher than in developing countries but still well below the averages in developed countries. Future growth of grain production via significant yield growth could be achieved by spreading the applications of updated hybrid seeds; balanced utilization of chemical fertilizer and pesticides; increasing use of other modern inputs such as plastic film, farming machines, as well as power for agriculture use; investment in agricultural infrastructure such as irrigation and drainage facilities; and agricultural research (Lin et al., 1996; World Bank, 1985, 1997a). ${ }^{5}$ In addition, the Ministry of Agriculture plans to classify over $80 \%$ of farmland as basic farmland conservation zones by 2010. The average increase in land productivity in the grain production for the period of $1950-1977$ was $3.1 \%$. There is a debate on the magnitude of the future performance of grain production. Estimations of annual yield increases in grain production vary between 0.5 and $2 \%$ depending on assumptions of investment in research and irrigation, world price impact, salinity and erosion, and opportunity costs of labor and land (Huang and Kalirajan, 1997b; Lin et al., 1996; World Bank, 1997b).

For our scenarios, we follow the Agricultural Action Plan of China's Ministry of Agriculture with a target of grain yield per unit area increasing by $1 \%$ per year. We apply the same productivity growth rate to the other-crop sector.

In order to derive regional differences, we use an assessment of the crop production potential in China by Xie and Jia (1994) based on the AEZ method. This allows us to calculate regional differences based on natural factors assuming similar technologies in all of China. Xie and Jia developed three production scenarios corresponding to the low, medium, and high input level, based on those considerations as we listed in Section 2.

The productivity of grasslands in China is much lower than in other parts of the World, which severely limits the development of China's livestock industry. The Ministry of Agriculture (1999) states that China has a serious problem of grassland degradation, with over $50 \%$ of the northern grassland being degrading and the remainder degrading at the rate of $1.9 \%$ annually. To maintain and further improve the quality of grassland, the Ministry plans to apply measures such as pest and rodent control, monitoring, conservation zones, and enclosed pastures. The improvement of 25 million ha of pasture is planned by the year of 2010. The Ministry hopes that China can maintain a stable output of animal husbandry in the pastoral areas before 2010 and can start to increase the pastoral land productivity afterward. Given the very limited capability of the grazing mode, it is widely expected that by 2020 , feeding mode would produce more than $80 \%$ of the total livestock output (ibid). We put this figure at about $85 \%$ for 2025 . In line with the expectation of the Ministry (ibid), we assume an accumulative land productivity growth of $25 \%$ for the whole period of $1992-2025$ in the pasture sector.

\footnotetext{
${ }^{5}$ It should be noted that the current consensus in China is promoting high-value-added and labor-intensive rather than the western-type of capital-intensive agriculture.
} 
In the calculation of land requirement coefficients for the livestock sector, it is worth noting that the real land requirement would be a combination of the direct land uses, including pasture land and those land uses for keeping pork and poultry, and the indirect land uses for growing processed and unprocessed feed-crops. Once the scenarios of land productivity growth for both the cropping and pastoral sectors are established, the overall land-productivity growth in the livestock sector can be interpreted as the value-share weighted average of the corresponding growth in the cropping and pastoral sectors.

To derive the regional variation on land productivity growth in the livestock sector, we use the estimation by Zheng and Tang (1994). Their assessment of grassland productivity consists of two major parts - the calculation of the primary production (forage output) and the secondary production (livestock products). The calculation of the forage is based on the AEZ method. To receive the feed supply potential, the yields for each zone were adjusted by feed intake rates of livestock and different dehydration rates for hay-making for different grassland types (ibid, pp.33). In the second step, the characteristics of the livestock system were highlighted and different herd proportions and livestock production potentials were calculated based on the balance between feed supply potential and feed requirements.

The incremental output from the low-input assessment to the mediate-input assessment show a clear variation across regions. We use this variation to distribute average national productivity-growth rate to the regional level.

With respect to forestry, even the estimations of current forest stock are quite diverse. For example, Fischer et al. (1996) report that the stock has steadily increased, from about 7 billion cubic meters $\left(\mathrm{m}^{3}\right)$ in the 1950 s to about 10 billion $\mathrm{m}^{3}$ in the late 1980s. Liu (1998) claims that timber stocks are drastically decreasing due to increased consumption, withering, fire damage, and insect damage. For 1992, Liu estimates the existing forest stock to be about 5.3 billion $\mathrm{m}^{3}$. Liu states that if no action were taken, China would lose all its timber stocks in the near future. Nilsson (1999) shows that the felling of industrial wood at the current rate of 197 million $\mathrm{m}^{3}$ per year exceeds the annual increment of 176 million $\mathrm{m}^{3}$ per year in growth of natural forests and industrial plantations. Shi and Xu (2000) on the other hand, using all four forest resource censuses data (Ministry of Forestry, 1978, $1983,1990,1996)$ show that the forest resource stock had been slightly increasing between 1973 and 1993 and the total timber stock was about 11.8 billion $\mathrm{m}^{3}$ in the early 1990s.

Based on the forest resource census data, which is relatively reliable and authoritative, we establish the productivity change scenarios for the forestry sector in line with Fischer et al. (1996), Shi and Xu (2000). We first calculate the land requirement coefficient in the forestry sector for 1992 directly from the total output of forest sector as provided by the $\mathrm{I}-\mathrm{O}$ tables and the corresponding areas. The resulting land coefficient at the national level is consistent with a sustainable yield factor of about $4.2 \mathrm{~m}^{3} /$ ha (Ministry of Agriculture, 1998; Shi and 
$\mathrm{Xu}, 2000$ ) while being weighted by the corresponding price figures of major forest products.

In consideration of the fact that timber densities in China are very low, with $30-84 \mathrm{~m}^{3} / \mathrm{ha}$ in comparison to World's timber densities of about $100 \mathrm{~m}^{3} / \mathrm{ha}$ (Ministry of Forestry, 1990) and that the efforts to improve forest management through property right reform, strengthening monitoring and preservation institutions, and employing other effective management practices are under way, we assume the accumulated productivity growth of $25 \%$ in this sector from 1992 to 2025. Due to the lack of AEZ assessment, we have to ignore the regional variation in growth for this sector.

Estimation of future land areas required for urban development, rural industrial agglomerations, and infrastructures is less straightforward. Due to the heterogeneity of industrial production, there is no systematic aggregate data available on land requirements of various industries beyond case studies on a local or regional level. In addition, international data includes usually commercial and industrial land with various shares of services and industrial production. Much of the infrastructure is already in place so that the improvement and extension of the infrastructure would only require marginal additions of land. Future development might mainly necessitate a restructuring of existing areas and infrastructures. It is difficult to say how redevelopment of urban areas and organizational changes will affect land productivity in the industrial sectors. Given the backward structure of Chinese industry there might be great possibility to have considerable increases in industrial value-added without any significant additional industrial land use, simply because most of this growth will be outside the traditional smoke-stack, heavy industry (and land-use intensive) activities.

Even if one assumes that the industrial areas would stay more or less the same, considerable additional land will be required for infrastructure development. The shortage of infrastructure has been considered one of the main bottlenecks to future economic development (EAAU, 1997; World Bank, 1985). China's annual investment in the transport and other infrastructure sectors has been small in comparison to other countries. Major investments in the extension of the current structure, as well as in increasing its efficiency are necessary. A good proxy for land-use consuming infrastructure is the future increase of roads. Currently, China averages $1.1 \mathrm{~km}$ of roads per $100 \mathrm{~km}^{2}$, in comparison to $7 \mathrm{~km} / 100 \mathrm{~km}^{2}$ in the USA and $4.7 \mathrm{~km} / 100 \mathrm{~km}^{2}$ in India, respectively. Even the better-developed coastal areas have only $2.5 \mathrm{~km} / 100 \mathrm{~km}^{2}$. Only $23 \%$ of China's roads are asphalt paved and most are in poor condition (CIA, 1999; EAAU, 1997, pp.228). Projections show that cars might more than triple within the next 10 years (TEI, 1994, quoted in World Bank, 1997a). In our study we distinguish the coastal regions from the inland and use two different growth rates of transportation infrastructure development for them in the period 1992-2025. For the coastal area, we assume a relatively high annual growth rate of $1.9 \%$, which would bring coastal China to the road-infrastructure level of 
Table 6

Necessary annual growth rates in land productivity (\%)

\begin{tabular}{lll}
\hline Economic sectors & Assumed growth rate in technology 2025 & Necessary growth rate $^{\mathrm{a}}$ \\
\hline Grain & 1.00 & 1.03 \\
Other crops & 1.00 & 2.04 \\
All crops & 1.00 & 1.28 \\
Forestry & 0.68 & 2.65 \\
Pasture & 0.68 & $1.12^{\mathrm{b}}$ \\
\hline
\end{tabular}

\footnotetext{
a These necessary annual growth rates will keep the demand specified in Scenario E within the land limits.

${ }^{\mathrm{b}}$ Once the production share of feeding mode is raised to 14 and $13 \%$, the corresponding necessary growth rates in the pastoral sector become 0.91 and $0.69 \%$, respectively.
}

today's India. For Central China and Western China, we assume annual growth rates of $1.6 \%$.

Table 3 summarizes these basic land-productivity scenarios for 2025 and presents them in the form of land requirement coefficients.

\section{Model results}

Given the commonly excepted scenarios for demographic, social, and economic changes as well as technological progress, sectoral outputs would drive the associated land requirements to exceed the available land area. In other words, China would not be able to support the increased demand for land-intensive products with its land base without significant improvement in land productivity and/or increasing imports. The major results of our scenario analysis at the national level are presented in Fig. 3.

In the category representing cultivated land, the scenarios that add, step by step, per capita income growth with the associated lifestyle change, urbanization, and higher population growth $(\mathrm{D}, \mathrm{E}, \mathrm{F})$ to the previous scenarios are exceeding the limits of available land. The biggest jump in demand for farmland is triggered by the income growth scenario (D). The difference between Scenario D and E indicates that given the income level, the land saving-effects of urbanization (more efficient use of infrastructure and residential land) would be offset by an increase in indirect demand for feed-grain triggered by the higher consumption of animal products.

In the case of grassland, the scenarios that add urbanization and higher population growth to the previous scenarios (E and F) are exceeding the available grassland areas. Similar to the case of cropland, the biggest jump in demand for additional grassland is caused by per capita income growth with the associated lifestyle change (D), in particular, by the significant increase in per capita meat 
consumption, given the pre-assumed production share of the pastoral sector in the total livestock production.

Similar to the case of cultivated land, the demand for forestry products exceeding the available forestland appears in the most aggregate scenarios (D, E, F).

It is worth noting that the desired high growth rate for land productivity in the livestock sector reflects the strong desire for feed grain growth. This indicates that there is a trade-off between the productivity growth rate of the grain sector and that of the livestock sector.

Table 6 presents a comparison of commonly expected growth rates in the literature and those necessary to keep the demand, as specified in Scenario E, within the land limits. We can see from this table that the required land productivity growth rate for other crops, forestry, and pasture are considerably higher than the ones commonly assumed in the literature.

Given the constraint of the immobile land availability and the technological scenario 'Technology 2025,' we proceed at both regional and national levels to show how much net import will be required to meet the regional and national demand for grain, other crops, livestock products and forest products. Table 7 reports the derived net import requirements.

At the national level, the net import demand for livestock products is at a scale of more than 100 billion (1992) Yuan, being equivalent to the domestic production cost of 100 million tons of wheat. The net import demand for products of the other crop sector is at an even larger scale. Such a large-scale net import of animal and crop products would go beyond the limits of political feasibility and the capacity of the world food market. Therefore, these figures would indicate that if maintaining the moderate pace of technical progress across these three major land use sectors, as assumed in Technology 2025, the other crop sector will compete with the grain sector for claiming much more land and the livestock sector will put much stronger pressure on the grain sector for feed-grain production than we have assumed before.

At the regional level, the highest requirements for net import of crop and livestock products correspond to the most developed regions East and South, closely followed by the better developed region North in the coastal zone as well. The traditional food export regions Northeast and Central continue to be the leading contributors to the national food pool, followed by the relatively backward region Northwest. The traditional food export region, Southwest, becomes one requiring a moderate net import of food. In terms of forest products, Northeast and the central government-run forest sector (including Plateau Region) continue to show their significant advantages in forest resource endowment, and the more industrialized regions in the coastal areas maintain to be net import regions. Whereas the region Southwest, which ranks second closely following the Northeast region in terms of rich forest resources, ends up with a moderate demand for net import. $^{6}$

\footnotetext{
${ }^{6}$ For a recent assessment on regional distribution of China's forest resources, see Albers et al., 1998.
} 
Table 7

Deficit or surplus of the major agricultural products at regional and national levels in 2025 (in million Yuan)

\begin{tabular}{|c|c|c|c|c|c|c|c|c|c|}
\hline Economic sectors & $\mathrm{R} 1-\mathrm{N}$ & R2-NE & R3-E & $\mathrm{R} 4-\mathrm{C}$ & R5-S & R6-SW & R7-NW & 7-Regions ${ }^{\mathrm{a}}$ & China $^{b}$ \\
\hline Grains & 14744 & 20331 & 11456 & 19522 & 10402 & 12154 & 11565 & 100173 & 18106 \\
\hline Other crops & -8457 & 8538 & -34470 & 18319 & -22431 & -19694 & 6787 & -51408 & -137562 \\
\hline Livestock & -18926 & 3318 & -41014 & 16046 & -17353 & -2719 & 3151 & -57497 & -104133 \\
\hline Forestry & -5163 & 751 & -551 & -19174 & -12383 & -85 & -1969 & -38574 & -34182 \\
\hline Sum & -17803 & 32938 & -64579 & 34713 & -41765 & -10345 & 19534 & -47306 & -257771 \\
\hline
\end{tabular}

Negative numbers means deficit and positive numbers mean surplus.

a Category '7-Regions' is the sum of Regions R1-R7.

${ }^{b}$ Differences between the categories 7-Regions and China represent the combination of Plateau region and the central government-run economic sector. 
Putting the seven regions together, their aggregate deficit in the livestock and other crop sectors can be balanced by their aggregate surplus in grain production. This would mean that there were no agricultural surplus left to meet the demand of the central government-run economic sector and to fill the food deficit of the Plateau Region, which has historically depended on food transfer from other regions to meet a large proportion of its food demand.

Both the above assessments of desired productivity growth and import strongly suggest that in order to meet the foreseen demand increase for major agricultural products, China needs to make greater efforts to improve land productivity in the cropping, pasture, and forestry sectors. China also needs to modernize its feeding mode in a fast pace in order to increase both output and efficiency in the farm-based livestock sector.

\section{Concluding remarks: implications for future land-use change}

In this paper, a set of diverse scenarios have been developed to show how population growth, changes in lifestyles, levels of urbanization and migration, and per capita income growth during the next decades might affect the demand for different types of land in China. Given the moderate pace of technological progress, as assumed in the scenario Technology 2025, the resultant increases in final demands and sectoral outputs would drive the associated land requirements to exceed the then available land area. All three land categories face shortages for the most-aggregate scenarios. If the traditional policy of grain and food self-sufficiency were maintained intact, to keep the farmland requirement feasible, an annual growth rate of cropland-productivity of about $1.28 \%$ would be required. Taking into account the implicit substitution between the productivity growth rate of the grain sector and that of the livestock sector, an even higher rate would be required to make a proper balance between these two sectors. On the other hand, it is widely believed that due to current inefficiencies and structural problems, land productivity in China's cropping agricultural sector may have ample room to significantly increase above current levels even without having to rely on future technologies but by further exploiting the best currently available practices (Ministry of Agriculture, 1998, 1999). With the help of newly available technology in the next two decades, China's cropping agriculture would have a great potential to reach a higher land productivity growth than $1.3 \%$ per annum.

To realize the desired productivity gains in the cropping sector, large investments are needed to develop additional and efficient water supplies by improving irrigation systems, as well as by increasing efficiency of on-farm use of water. The most significant contribution of sustainable and extended irrigation will occur in the regions North and Northwest. According to a recent AEZ assessment over the water issue in China (Heilig et al., 2000), if geophysically feasible irrigation can be guaranteed in these two regions, irrigation would be able to boost the gross grain production potential by about 100 million tons in the 
North and by 45 million tons in the Northwest, as compared with purely rain-fed cropping.

In terms of increasing application rate of fertilizer, new facilities using modern technologies for fertilizer production and imports will be necessary. Currently, China is importing some $20-25 \%$ of internationally traded fertilizer to meet about $30 \%$ of its fertilizer nutrient needs (World Bank, 1997a).

A well-known alternative to the policy of self-sufficiency is the import of grains. However, one bottleneck for this is the lack of infrastructure facilitating imports, such as port handling equipment and transit storage. Here, large investments are needed to improve grain-handling efficiency (World Bank, 1997a).

Further productivity growth is also required to compensate for loss and degradation of available cropland. Currently, much converted cropland to non-agricultural uses is used inefficiently by land-extensive development projects and 'horizontal' expansion of urban agglomerates. Strict measures must be implemented and enforced to minimize construction-related losses of cultivated land. China needs concepts for infrastructure development that minimize land requirements, especially in the rapidly developing coastal provinces.

Given today's practice in livestock production, China will have great difficulties to meet increasing demands for animal products. Transformation of livestock production from the peasant's backyard feeding mode and sedentary grazing to medium and large-scale 'factory' type of production systems, with growing dependence on modern feeding methods and genetic techniques introduced from abroad, has already begun. The shortage of grassland can be partly overcome by increasing the already high share of feed-grain production, but in doing so increasing the pressure on cropland. The competition between livestock production and urban and industrial uses for grassland is less pronounced than in the case of cropland due to its remote location from economic growth centers. However, the remoteness, prohibitive transportation costs and the lack of infrastructure pose severe hindrances for grassland to reach higher productivity rates.

The remoteness of the locations of major forests also makes it difficult to improve land productivity. In addition, excessive harvesting and insufficient regeneration have caused long-term deficits in stocking. The increasing needs for timber logs from a growing economy and the enormous demand for residential firewood will require increasing efficiency as well. Policies are needed to encourage such efforts as improving forest management, increasing forest densities, and maintaining stable political and institutional environments for long-term investment. While the importance of forestland for protecting cropland in fighting soil erosion and desertification has already been widely recognized, active and massive responses are still missing. Direct investments in regional reforestation projects show already some visible and encouraging impacts at the national level (Albers et al., 1998, pp.27). The quality of these planted forests, however, is so poor that they 
will not play any significant role in timber production in the near future (Yin, 1994).

To summarize, we can state that there is ample room for further growth in land productivity of major land use sectors of China's economy. However, it is uncertain that sufficient investments for the agricultural sector will be provided. The political goal of self-sufficiency in (regional) grain production will certainly collide with its high opportunity costs given the higher productivity of land and water for urban and industrial uses. Increasing shortages in land resources might lead to increasing interest in remote areas and to closer ties across the regions within China as well as to closer trading relationships with other parts of the world.

The results of our study have to be viewed with caution. Even if future land requirements could be satisfied, we have not yet assessed the sustainability of the utilization of land by the various economic sectors. Also questions of diversity are not addressed. For example, decreasing diversity and elimination of old growth forests may be considered the most serious environmental problem in the forest sector (Rozelle et al., 1998). In the cropping agricultural sector, the reclamation and yield growth potential are largely dependent on irrigation and water control. At this point of the $\mathrm{I}-\mathrm{O}$ analysis, we do not make any estimation of water availability and its effects on future land-use changes. In addition, some productivity growth scenarios presented in this paper imply a higher use of pesticides, fertilizer, fossil fuel and equipment. In this regard, future work should also pay attention to the energy needs, the emission of greenhouse gases, and other pollutants accompanying with the various development and technical options of the primary sectors. Another direction for future work may be to incorporate the possible impacts of climate changes into the $\mathrm{I}-\mathrm{O}$ modeling framework.

\section{Acknowledgements}

The authors thank Faye Duchin, Günther Fischer, Xiubin Li, Sylvia Prieler, Bert Steenge, Harry T. van Velthuizen, and two anonymous referees of this Journal for their comments, advices, and assistances.

\section{References}

Albers, H.J, Rozelle, S.D., Li, G., 1998. China's forests under economic reform: timber supplies, environmental protection, and rural resource accesss. Contemporary Economic Policy XVI, 2223.

Budavari, P., 1981. Generalization of RAS Method: Linear Restrictions with Strictly Convex Distance Function (Duality Theory and Algorithm). Proceedings of the Third Hungarian Conference on Input-Output Techniques, Heviz.

Chen, X., Wang, Z., Guo, J., 1996. China's Grain Supply and Demand in the 21 st Century Bulletin of the Chinese Academy of Science, 10. 
CIA, 1999. The World Factbook 1999 Central Intelligence Agency, Office of Public Affairs, Washington, DC.

Duchin, F., Lange, G.-M., 1992. Case Study Methodology. Institute for Economic Analysis. New York University, New York.

Duchin, F., Lange, G.-M., 1994. The Future of the Environment: Ecological Economics and Technological Change. Oxford University Press, New York.

Duchin, F., Hamilton, C., Lange, G.-M., 1993. Environment and Development in Indonesia: An Input-Output Analysis of Natural Resource Issues. Associates in Rural Development and Institute for Economic Analysis, New York University for USAID, Jakarta.

EAAU, 1997. China Embraces the Market: Achievements, Constraints, and Opportunities. Australian Department of Foreign Affairs and Trade, Barton, Australia.

FAO, 1995. Livestock: A Driving Force for Food Security and Sustainable Development. FAO, Feed Resources Group (R. Sansoucy), Rome.

FAO/IIASA, 1993. Agro-Ecological Assessment for National Planning: The Example of Kenya. Food and Agriculture Organization of the United Nations, Rome, Italy.

FAOSTAT, 1998. Food Balance Sheets. Food and Agricultural Organization, Rome, Italy.

Fischer, G., Makowski, M., 2000. In: Wierzbicki, A.P., Makowski, M. (Eds.), Land Use Planning, in Model-Based Decision Support Methodology with Environmental Applications. Kluwer Academic Publishers, Dordrecht, Netherlands.

Fischer, G., Zhao, Y.L.M., Sun, H., 1996. Land-Use Change in China: Land Resources and Contemporary Land Use. LUC project, internal working manuscript. International Institute for Applied Systems Analysis, Laxenburg, Austria.

Fischer, G., Chen, Y., Sun, L., 1998. The Balance of Cultivated Land in China during 1988-1995, IR-98-047. International Institute for Applied Systems Analysis, Laxenburg, Austria.

Flegg, A.T., Webber, C.D., Elliott, M.V., 1995. On the appropriate use of location quotients in generating regional input-output tables. Regional Studies 29 (6), 547-561.

Gardner, G., 1996. Shrinking Fields: Cropland Loss in a World of Eight Billion. Worldwatch Paper Worldwatch Institute, Washington, DC.

Heilig, G., 1999. Can China Feed Itself? International Institute for Applied Systems Analysis. Laxenburg, Austria. CD Rom.

Heilig, G.K., Fischer, G., van Velthuizen, H., 2000. Can China Feed itself? An Analysis of China's Food Prospects with Special Reference to Water Resources. International Journal of Sustainable Development and World Ecology.

Huang, J.K., Rozelle, S., 1997a. Environmental stress and grain yields in China. American Journal of Agricultural Economics 77 (4), 853-864.

Huang, Y., Kalirajan, K.P., 1997b. Potential of China's grain production: evidence from the household data. Agricultural Economics 17, 191-199.

Huang, J., Rozelle, S., 1998. China's Grain Economy to the Twenty-First Century. Agriculture Press, Beijing, China.

Huang, J., Chen C., 1999. Effects of Trade Liberalization on Agriculture in China: Commodity Aspects. CGPRT Centre, Jalan Merdeka, Indonesia.

Idenburg, A., 1993. Gearing Production Models to Ecological Economic Analysis: A Case Study, within the Input-Output Framework, of Fuels for Road Transport. Faculteit der Besturrskunde. Universiteit Twente, Enschede.

Jiang, Z., Zhang, E. (Eds.), 1998. Population Forecasting at the Provincial Level for China. China Population Publishing House, Beijing, China.

Lewis, B.D., Thorbecke, E., 1992. District-level economic linkages in Kenya: evidence based on a small regional social accounting matrix. World Development 20 (6), 881-897.

Lin, J.Y, Huang, J., Rozelle, S., 1996. China's Food Economy: Past Performance and Future Trends, in China in the 21 st Century: Long-Term Global Implications, OECD (Ed.) Organization for Economic Co-operation and Development, Paris.

Liu, X., 1998. Adjusted forest accounts for China. Ecological Economics 27, 283-298. 
Liu, A., Yao, S., Zhang, Z, 1999. Economic growth and structural changes in employment and investments in China, 1985-94. Economics of Planning 32, 171-190.

Mayer, W., Pleeter, S., 1975. A theoretical justification for the use of location quotients. Regional Science and Urban Economics 5, 343-355.

Miller, R.E., Blair, P.D., 1985. Input-Output Analysis: Foundations and Extensions. Prentice-Hall, Englewood Cliffs, New Jersey.

Ministry of Agriculture, 1998. Chinese Reserve Resources for Agriculture, Regional Planning Office for National Agricultural Resources. Beijing, China.

Ministry of Agriculture, 1999. Agriculture Action Plan for China's Agenda 21, Agriculture Press, Beijing, China.

Ministry of Forestry, 1978. National Forest Resource Statistics (1973-1976), Beijing, China.

Ministry of Forestry, 1983. National Forest Resource Statistics (1977-1981), Beijing, China.

Ministry of Forestry, 1990. National Forest Resource Statistics (1984-1988), Beijing, China.

Ministry of Forestry, 1996. National Forest Resource Statistics (1989-1993), Beijing, China.

Nilsson, S., 1999. The Forest Sector of China. FOR project-internal working manuscript, International Institute for Applied Systems Analysis, Laxenburg, Austria.

Parikh, A., Thorbecke, E., 1996. Impact of rural industrialization on village life and economy: a social accounting matrix approach. Economic Development and Cultural Change 44 (2), 351-377.

Price Statistical Yearbook of China, 1992. China Statistics Press Beijing, China.

Rozelle, V., Huang, J., 1997. The impact of environmental degradation on grain production in China: 1975-1990. Economic Geography 73 (1), 44-66.

Rozelle, V., Benzinger, V., Li, G., Huang, J., 1998. Forest exploitation and protection in Reform China: assessing the impact of policy, tenure and economic growth. Manuscript, China Center for Agricultural Policy, Beijing, China.

Shen, J., Spence, N.A., 1996. Modeling urban-rural population growth in China. Environment and Planning A 28, 1417-1444.

Shi, P., Xu, J., 2000. Deforestation in China. Manuscript.

State Statistical Bureau, 1993. Statistical Yearbook of Rural China. Statistical Publishing House, Beijing, China.

State Statistical Bureau of China, 1996. 1992 Input-Output Table of China (in Value) Statistical Publishing House, Beijing, China.

State Statistical Bureau of China, 1997. 1992 Regional Input-Output Tables of China (in Value), Diskettes, Department of Economic Accounting at State Statistical Bureau, Beijing, China.

Subramanian, S., Sadoulet, E., 1990. The transmission of production fluctuations and technical change in a village economy: a social accounting matrix approach. Economic Development and Cultural Change 39 (1), 131-175.

Sun, L., 2000. The Specification of the LUC Core Model for GAMS Implementation. LUC project, internal working manuscript. International Institute for Applied Systems Analysis, Laxenburg, Austria.

Sun, L., Li, X., 1997. Driving Forces of Arable Land Conversion in China, Interims Report IR-97-076. International Institute for Applied Systems Analysis, Laxenburg, Austria.

TEI, 1994. The Development Strategy for Cars to be Used by Households in China. Economic Daily.

United Nations Population Division, 1998. World's Population Prospects 1950-2050: The 1998 Revision. New York.

World Bank, 1985. China: Agriculture to the Year 2000. The World Bank, Washington, DC.

World Bank, 1992. Reform and the Role of the Plan in the 1990s. The World Bank, Washington, DC.

World Bank, 1997a. At China's Table: Food Security Options. The World Bank, Washington, DC.

World Bank, 1997b. China 2020: Development Challenges in the New Century. The World Bank, Washington, DC.

Wu, H.X., Findlay, C., 1997. China's Grain Demand and Supply: Trade Implications, in Agricultural Policies in China. Organisation for Economic Co-operation and Development, Paris.

Xie, J., Jia, K., 1994. Assessment of Crop Production Potential. Land Resources, Use and Productivity Assessment in China. State Land Administration of China; FAO, The Program Working Group of The Population-Bearing Capacity of Land in China: Beijing. 
Yin, R., 1994. China's Rural Forestry since 1949. Journal of World Forest Resource Management 7, 73-100.

Zheng, Z., Tang, C., 1994. Assessment of Livestock Production Potential. Land Resources, Use and Productivity Assessment in China. State Land Administration of China; FAO. The Program Working Group of The Population-bearing Capacity of Land in China, Beijing. 


\section{Ordering Information}

Orders must include the publication number and should be sent to the Publications Department, International Institute for Applied Systems Analysis, A-2361 Laxenburg, Austria.

Telephone: +432236807

Telefax: +43223671313

E-mail: molina@iiasa.ac.at

A full list of IIASA publications is available at www.iiasa.ac.at 
International institute for Applied Systems Analysis

Schlossplatz 1, A.2361 Laxenburg, Austria

Tel: +432236807 Fax: +43223671313

II ASA muw iiasa.ac.at 